\title{
Comparative partition coefficients of BTEX and OCPs between host Synodontis clarias and parasite Wenyonia acuminata
}

\author{
B. Akinsanya ${ }^{*}$, P. O. Isibor ${ }^{2}$, M. P. Kuton ${ }^{3}$ E. O. Dada ${ }^{4}$ and J. K. Saliu
}

\begin{abstract}
Background: The study was aimed at comparing the bioaccumulation of BTEX and organochlorine pesticides (OCP) in the intestine of host fish-Synodontis clarias relative to water and in its parasite-Wenyonia acuminata relative to host intestine. The study was carried out in Lekki lagoon, Nigeria, between April and August, 2017. BTEX was analyzed in water, fish, and parasite tissues using the EPA method 8260B Agilent 7890B gas chromatograph coupled to a mass spectrophotometer (GC-MS). Organochlorophosphate (OCP) was analyzed in tested media using Agilent 7890B gas chromatograph coupled to flame ionization detector (FID).

Results: High concentrations of most BTEX components such as benzene, toluene, chlorobenzene, ethylbenzene, metaand para-xylene ( $m+p$-xylene), and ortho-xylene (o-xylene) bioaccumulated into the intestinal tissues of $S$. clarias from the water medium. This is partly attributable to the fact that the $S$. clarias is a detritus and bottom feeder and to the hydrophilic properties of the components of BTEX. Despite the significant concentrations of benzene, toluene, and chlorobenzene accumulated in the intestine of $S$. clarias, no intestine-parasite partition coefficient was observed in the $W$. acuminata, i.e., the chemicals were not accumulated by the intestinal parasite. This is attributable to very low bioaccumulation factors of the chemicals in W. acuminata. W. acuminata exhibited significant bioaccumulation of 4,4DDT, endosulfan 1, aldrin, and heptachlor, irrespective of their concentrations in the water and intestine of $\mathrm{S}$. clarias. This indicates high affinity for the OCPs in the parasites.

Conclusion: Synodontis clarias of Lekki lagoon showed higher vulnerability to the BTEX than the OCPs in the aquatic habitat. This implies that Lekki lagoon was impacted by oil-related anthropogenic activities. Weyonia acuminata exhibited some tendency to alleviate concentrations of the OCPs in S. clarias. It is more imperative to mitigate the activities that release BTEX into the aquatic environment.
\end{abstract}

Keywords: Detoxification, Toxicity burden, Bioaccumulation factor, Intestine, Parasite

\section{Background}

The acronym BTEX refers to specific family of chemicals which are volatile organic compounds. Such compounds include benzene, toluene, ethylbenzene, and xylene. Natural sources of BTEX are forest fires and volcanoes. These compounds are constituents of crude oil, hence their occurrence in sea water is associated with natural gas and petroleum-related anthropogenic activities. BTEX compounds are among the most produced chemicals in the world. They are associated with the production of

\footnotetext{
*Correspondence: bamidele992@gmail.com

'Department of Biological Science, Covenant University, Ota, Ogun State, Nigeria

Full list of author information is available at the end of the article
}

petroleum products, paints, lacquers, pharmaceutical products, thinners, rubber products, adhesives, ink, and cosmetic products (Akinsanya, Goh, Lim, \& Tinga, 2015). Benzene is recognized as a carcinogenic compound, while the others (toluene, ethylbenzene, and xylene) are regarded as non-carcinogenic. Several studies have demonstrated the effects of exposure to BTEX on fish. Exposure of fish to other hydrocarbons have also been widely reported (Akinsanya, Goh, Lim, \& Tinga, 2015; Sogbanmu et al., 2016).

The organochlorine pesticides (OCPs) on the other hand, are broad-spectrum insecticides, and are the most widely used in many countries including Nigeria for agricultural purposes and control of mosquitoes (Blaso, 
Font, \& Pico, 2005; Bouman, 2004). Organochlorine pesticides are very stable compounds and it has been cited that the degradation of dichlorodiphenyltrichloroethane (DDT) in soil ranges from 4 to 30 years, while other chlorinated compounds are stable for many years after application, due to a high resistance to chemical and biological degradations (Afful, Anim, \& Serfor-Armah, 2010).

The top position of man in the food chain exposes him to consequences of biomagnification through alimentation (Belta et al., 2006; Raposo, Marks, \& Cutler, 2007). BTEX and OCPs are persistent liposoluble compounds, i.e. they are capable of bio-accumulating in fatty tissues of biota via the food chain. They have also been detected in breast milk and blood (William et al., 2008)

BTEX and OCPs have become ubiquitous contaminants. They are implicated in a broad range of deleterious health effects such as reproductive failures (Bouman, 2004), immune system malfunction (Kolpin, Thurman, \& Lingart, 1998), endocrine disruption (Ize-Iyamu, Asia, \& Egwakhide, 2007), and breast cancers (Garabrant, Held, Langholz, Peter, \& Mark, 1992). Previous studies have shown that DDT has the ability to block potassium influx across membranes of nerve fibers, thereby causing increased negative after-potentials. It also induces mixed function oxidize system, thereby alters the metabolism of xenobiotics and steroid hormones (Colborn \& Smolen, 1996). The persistence of BTEX and OCPs, their bioaccumulation tendency, and global contamination resulted in their ban and restriction in many countries. Despite their restriction, these compounds are still detected in the environment and in tissue samples.

The Squeaker or upside-down catfish-Synodontis clarias (Linnaeus, 1758) - is a benthopelagic, potamodromous fresh water fish that inhabits water with a $\mathrm{pH}$ range of 6.5-9.5 (Riede, 2004). The fish exhibits dioecism with external fertilization (Breeder \& Rosen, 1966) which is easily impacted by xenobiotics. Nigerian coastal fishes, including S. clarias have been reported to contain some residues of BTEX and OCPs (Adeyemi, Ukpo, Anyakora, \& Unyimadu, 2008; Osibanjo \& Bamgbose, 1990; Osibanjo et al., 2002; Unyimadu \& Udochu, 2002).

Due to low fat composition, fish endoparasites are not able to bioconcentrate lipophilic substances above the levels of the host tissues (Akinsanya, Ukwa, \& Hassan, 2014). However, they more readily bioaccumulate toxicants than more than many free-living sentinel species (Akinsanya, Goh, Lim, \& Tinga, 2015).

Ecotoxicological effects linked to OCPs and BTEX in Lekki lagoon are from municipal sources (Yao et al., 2013), and oil companies (Akinsanya et al., 2019) respectively. Comparative analysis of OCPs and BTEX may give an insight to the source of greater impacts on the aquatic environment. Results of the findings may advance ecotoxicological mitigation efforts

The study was therefore aimed at comparing the bioaccumulation of two groups of BTEX and OCPs in the intestine of Synodontis clarias and ultimately in its parasite Wenyonia acuminata.

\section{Materials and methods}

\section{Description of study area}

The study was carried out on Lekki lagoon (freshwater), which makes up a part of large and diverse system of water ways. It is a combination of different lagoons found along the part of the land adjoining of the South-western Nigeria, stretching over a distance of about $200 \mathrm{~km}$. The Osun and Oni River are the main rivers discharging into the North-Western and North-Eastern parts of the lagoon. Vegetation around the lagoon is characterized by stilt rooted trees with dense undergrowth of shrubs and herbs such as Raphia sudanica, Elaeis guineensis, and the Cocos nucifera (coconut palms) which is found widespread in the surrounding villages (Edokpayi, Uwadiae, Asoro, \& Badru, 2008; Lawal et al., 2010). The rich fish of the lagoon includes Heterotis niloticus, Gymnarchus niloticus, Clarias gariepinus, Malapterurus electricus, Synodontis clarias, Chrysichthys nigrodigitatus, Parachanna obscura, Mormyrusrume, Calabaricus calamoichthys, Tilapia zilli, Tilapia galilae, Hemichromis fasciatus, and Sarotherodon melanotheron (Kusemiju, 1981).The lagoon is located in Lagos State, South-West, Nigeria. It lies between longitudes $4^{\circ} 00^{\prime}$ and $4^{\circ} 15^{\prime} \mathrm{E}$ and between latitudes $6^{\circ} 25^{\prime}$ and $6^{\circ} 37^{\prime} \mathrm{N}$, has a surface area of about $247 \mathrm{~km}^{2}$ with a maximum depth of $6.4 \mathrm{~m}$, though a greater portion of the lagoon is shallow with less than $3.0 \mathrm{~m}$ deep (Fig. 1).

\section{Sample collection and analysis}

Fishes from the wild were randomly collected at the sample location. This fish were purchased at Oluwo Market from local fishmongers who are based at the Epe jetty, Lagos, Nigeria. A total of $120(\mathrm{SL}=14.6-22.5 \mathrm{~cm})$ samples were collected most of which were still living. The specimens were collected on nine trips over a period of 5 months (April to August, 2017). The sex and maturity of the collected specimens were determined by gross examination of the gonad.

The standard lengths and total lengths of the fishes also were recorded using a measuring ruler. Each fish was slit open from the urogenital opening through the operculum. Specific internal organs (Liver and gastrointestinal tract) were then carefully extracted and placed in an arranged petri dishes filled with saline solution. Examination of parasites present within the intestinal tract was carried out using the techniques of Akinsanya, Otubanjo and Hassan (2007). 


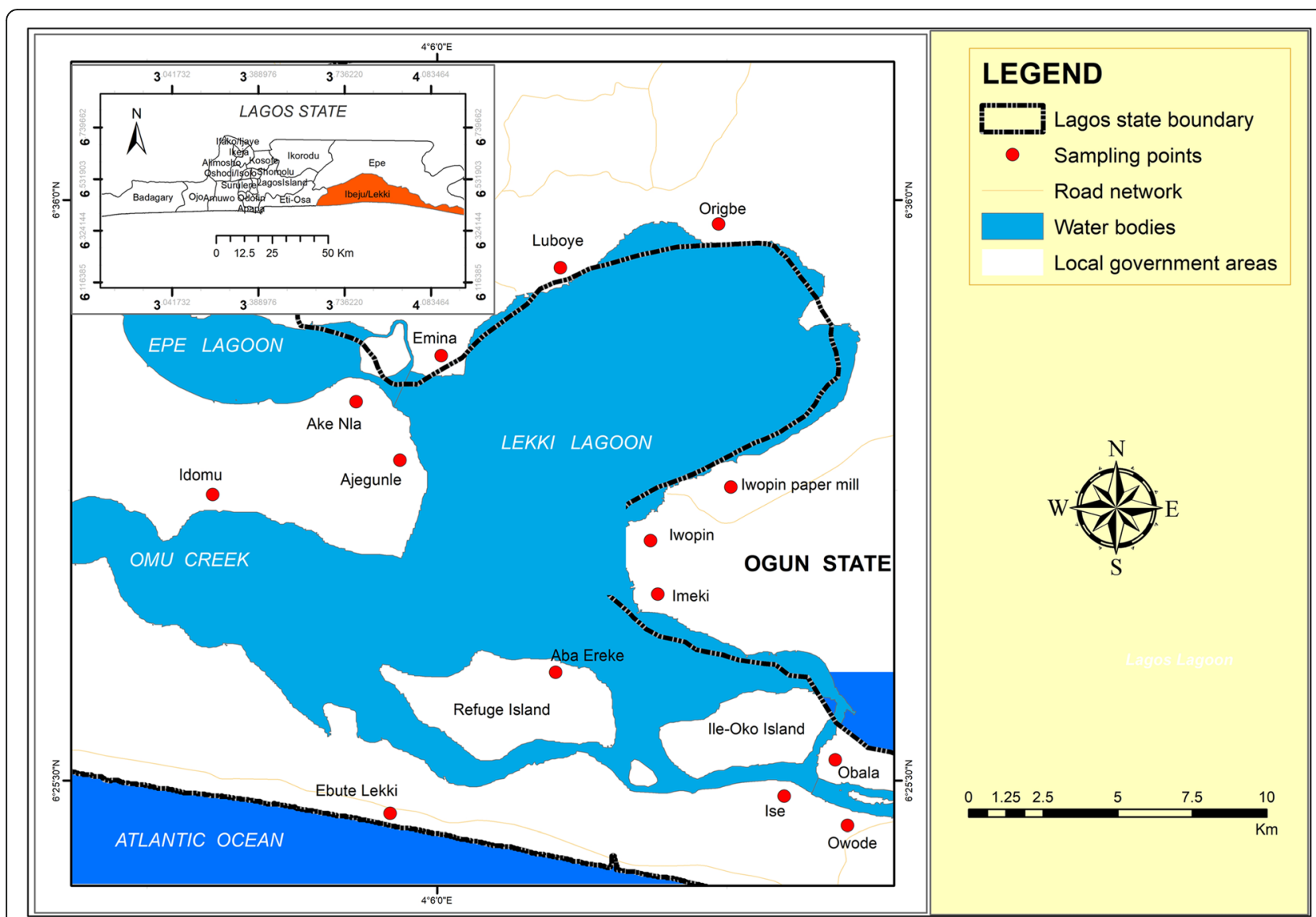

Fig. 1 Map showing Epe Lagoon (Inyang et al., 2016)

The intestines were eviscerated and open from the anterior to the posterior end to aid parasite emergence using sterile blades. The emergence of parasite was carefully observed through its movement in the solution with the aid of a hand lens. The viewed parasites were counted and recorded before being kept in saline solution. Intestines were stored in labeled universal sample bottles with saline while some were in Bouin's fluid before taking for analysis. The parasites were also kept in sample bottles containing saline solution.

BTEX was analyzed in water, fish, and parasite tissues using the EPA method 8260B Agilent 7890B gas chromatograph coupled to a mass spectrophotometer (ASTM, 1997). The stationary phase of separation of the compounds used was a DB-5 capillary column coated with $95 \%$ dimethyl$5 \%$ diphenyl polysiloxane $(30 \mathrm{~m}$ length $\times 0.32 \mathrm{~mm}$ diameter $\times 1.0 \mu \mathrm{m}$ film thickness) (Agilent Technologies). Then, $1 \mu \mathrm{L}$ of the samples was injected in split mode with split ratio 100:1 at an injection temperature of $125^{\circ} \mathrm{C}$, oven was initially programmed at $35^{\circ} \mathrm{C}$ (held for $2 \mathrm{~min}$ ) then ramped at $4{ }^{\circ} \mathrm{C} / \mathrm{min}$ to $50{ }^{\circ} \mathrm{C}$ and then $10{ }^{\circ} \mathrm{C} / \mathrm{min}$ to $220{ }^{\circ} \mathrm{C}$, helium flow rate was set at $1.5 \mathrm{~mL} / \mathrm{min}$, while the mass range was set at 35-260 amu and scan time at $0.6 * 2 \mathrm{~s} / \mathrm{scan}$.
OCP was analyzed in tested media using Agilent 7890B gas chromatograph coupled to flame ionization detector (FID), according to the description of Yao et al. (2013). The stationary phase of separation of the compounds used was a HP-5 capillary column coated with 5\% phenyl methyl siloxane $(30 \mathrm{~m}$ length $\times 0.32 \mathrm{~mm}$ diameter $\times 0.25 \mu \mathrm{m}$ film thickness) (Agilent Technologies). Then, $1 \mu \mathrm{L}$ of the samples was injected in splitless mode at an injection temperature of $300{ }^{\circ} \mathrm{C}$, at a pressure of $13.74 \mathrm{psi}$, and a total flow of $21.364 \mathrm{~mL} / \mathrm{min}$. Purge flow to split vent was set at $15 \mathrm{~mL} / \mathrm{min}$ at $0.75 \mathrm{~min}$. Oven was initially programmed at $40{ }^{\circ} \mathrm{C}$ $(1 \mathrm{~min})$ then ramped at $12{ }^{\circ} \mathrm{C} / \mathrm{min}$ to $300{ }^{\circ} \mathrm{C}(10 \mathrm{~min})$. FID temperature was $300{ }^{\circ} \mathrm{C}$ with hydrogen:air flow at $30 \mathrm{~mL} / \mathrm{min}: 300 \mathrm{~mL} / \mathrm{min}$ while nitrogen was used as makeup gas at a flow of $22 \mathrm{~mL} / \mathrm{min}$.

Water samples were collected from 14 selected stations (Fig. 1) in pretreated sampling bottles and preserved in ice chest for laboratory analysis of BTEX and OCP concentrations. Physicochemical parameters of water at the selected stations were measured in-situ.

Temperature was measured using a mercury-inglass-thermometer, while salinity, dissolved oxygen, $\mathrm{pH}$, 
turbidity, total suspended solids (TSS), and total dissolved solids (TDS) and conductivity were measured using a handheld multi-parameter probe (Horiba Water Checker Model U-10).

\section{Quality assurance}

Samples were carefully handled to avoid contamination. Appropriate sample preservation and labeling were ensured. Glasswares were properly cleaned, and reagents were of analytical grades. Deionized water was used throughout the study. Reagent blank determinations were used to correct the instrument readings, and rLekkiated calibration of analytical equipment was done. Fish used for the experiment were purchases fresh. All experiments procedures and methods were performed in accordance with standard scientific guidelines and regulations.

\section{Statistical analysis}

All indices were statistically analyzed at significance level of 5\% $(p<0.05)$. The Statistical Package for Social Sciences (SPSS, version 20) and Microsoft Office Excel software were deployed in this study. Tables and graphs were plotted with the use of MS Words and Excel 2016 while QP 3.0 (Quantitative parasitology software) was used to analyze the prevalence, mean, and median intensity of parasite infestation.

The parasites discovered were identified as Wenyonia acuminata (Akinsanya, Ukwa, \& Hassan, 2014). Parasites were counted, fixed in $70 \%$ alcohol, and recorded accordingly.

Parasitic mean intensity was calculated using the formula stated by Ezewanji et al. (2005) and Saliu et al. (2014).

$$
\begin{aligned}
\% \text { Prevalence }= & \frac{\text { Number of infected fish }}{\text { Number of fish examined }} \\
& \text { X } 100 \text { (Ezewanji et al., 2005) }
\end{aligned}
$$

Parasite abundance $=\frac{\text { Number of collected parasites }}{\text { Number of fish examined }}$

$$
\text { X } 100 \text { (Saliu et al., 2014) }
$$

$$
\text { Mean intensity }=\frac{\text { Number of collected parasites }}{\text { Number of infected fish }}
$$

X 100 (Saliu et al., 2014)

\section{Results}

All physicochemical properties of water in Epe lagoon were within the standard regulatory limit of FEPA (Table 1).

We studied the abundance of W. acuminata of $120 \mathrm{~S}$. clarias collected from Epe Lagoon (Table 2). A total of 12 out of 107 males, and 8 out of 13 females were
Table 1 Physiochemical parameters of water in Epe lagoon

\begin{tabular}{lll}
\hline Parameters & Concentrations & FEPA (2003) \\
\hline Temperature $\left({ }^{\circ} \mathrm{C}\right)$ & $25.8 \pm 0.3$ & $<40$ \\
$\mathrm{pH}$ & $6.5 \pm 0.1$ & $6-9$ \\
$\mathrm{DO}(\mathrm{mg} / \mathrm{L})$ & $8.7 \pm 0.2$ & $>5.0$ \\
$\mathrm{TSS}(\mathrm{mg} / \mathrm{L})$ & $9 \pm 1.5$ & 30 \\
$\mathrm{TDS}(\mathrm{mg} / \mathrm{L})$ & $110.1 \pm 5.6$ & 2000 \\
Conductivity $(\mu \mathrm{S} / \mathrm{cm})$ & $172.8 \pm 2.6$ & 400 \\
Salinity $(\mathrm{ppt})$ & $4.5 \pm 0.5$ & $\mathrm{NA}$ \\
Turbidity $(\mathrm{NTU})$ & $8.57 \pm 2.5$ & 10 \\
\hline
\end{tabular}

infected with $W$. acuminata. This amounted to low mean parasite intensity of $3(14.6-16.5 \mathrm{~cm}), 3.5(16.6-$ $19.5 \mathrm{~cm})$, and $2(19.6-22.5 \mathrm{~cm})$, while the mean intensity in the female was $1(14.6-16.5 \mathrm{~cm}), 1(16.6-19.5 \mathrm{~cm})$, and $0.5(19.6-22.5 \mathrm{~cm})$ among the various length cohorts analyzed. Result shows that the parasites in the $S$. clarias of Epe lagoon are not of significant intensity.

The concentrations of benzene and chlorobenzene detected in the intestine of the fish were significantly higher $(p<0.05)$ than the concentrations detected in the water and parasite (Table 3 ). There was no significant difference $(p>0.05)$ in the concentrations of toluene and 1,4-dichlorobenzene in the water and the intestine of fish; these concentrations were however higher than the concentration detected in the parasite. The concentrations of ethylbenzene, meta- and para-xylene $(\mathrm{m}+$ p-xylene), and o-xylene detected in the intestinal tissue of $S$. clarias and its endoparasite (Procamallanus aevionchus) were significantly higher $(p<0.05)$ than the concentrations detected in the water medium. The concentrations of 1,3-dichlorobenzene was significantly higher in the water than in the fish and its parasite, in which the chemical was completely absent. On the whole, the trend of total BTEX in the Lekki lagoon

Table 2 Intensity of W. acuminata in S. clarias relative to standard length

\begin{tabular}{lllllll}
\hline Sex & SL $(\mathrm{cm})$ & NE & NI & Prevalence (\%) & Abundance & $\begin{array}{l}\text { Mean } \\
\text { intensity }\end{array}$ \\
\hline Male & $(14.6-16.5)$ & 10 & 2 & 10 & 0.6 & 3 \\
& $(16.6-19.5)$ & 56 & 4 & 7.1 & 0.3 & 3.5 \\
& $(19.6-22.5)$ & 41 & 8 & 19.5 & 0.4 & 2 \\
Total & & 107 & 12 & 11.2 & 1.3 & 8.5 \\
Female & $(14.6-16.5)$ & 2 & 2 & 100 & 1 & 1 \\
& $(16.6-19.5)$ & 7 & 3 & 42.9 & 0.1 & 1 \\
& $(19.6-22.5)$ & 4 & 3 & 75 & 0.5 & 0.5 \\
Total & & 13 & 8 & 46.2 & 1.6 & 2.5 \\
\hline
\end{tabular}

Chi-square $\left(X^{2}(3)\right) 12.57(p<0.05)$

$S L$ standard length, $N E$ number examined, $N I$ number infected, $M I$ mean intensity of parasite 
Table 3 Bio-concentration factor of BTEX in water-fish (Synodontis clarias)-parasite (Procamallanus laevionchus) transit

\begin{tabular}{|c|c|c|c|c|c|}
\hline Components (ppm) & $\begin{array}{l}\text { Water }(\mathrm{ppm}) \\
\text { Mean } \pm \text { SD }\end{array}$ & $\begin{array}{l}\text { Intestine (ppm) } \\
\text { Mean } \pm \text { SD }\end{array}$ & $\begin{array}{l}\text { Parasite (ppm) } \\
\text { Mean } \pm \text { SD }\end{array}$ & BAFI/W & BAFP/I \\
\hline Benzene & $2.765 \pm 0.60$ & $18.3^{*} \pm 2.7$ & $0.000 \pm 0.00$ & 6.000 & 0.000 \\
\hline Toluene & $2.690^{*} \pm 0.61$ & $3.369^{*} \pm 0.68$ & $0.000 \pm 0.00$ & 1.000 & 0.000 \\
\hline Chlorobenzene & $1.900 \pm 0.64$ & $4.231^{*} \pm 0.67$ & $0.000 \pm 0.00$ & 2.000 & 0.000 \\
\hline Ethylbenzene & $3.890 \pm 0.73$ & $6.342^{*} \pm 0.12$ & $7.460^{*} \pm 0.38$ & 2.000 & 1.000 \\
\hline$m+p$-Xylene & $0.980 \pm 0.33$ & $7.409^{*} \pm 1.23$ & $6.861^{*} \pm 0.23$ & 7.000 & 1.000 \\
\hline O-xylene & $1.890 \pm 0.21$ & $5.281^{*} \pm 1.09$ & $5.824^{*} \pm 0.41$ & 3.000 & 1.000 \\
\hline 1,3-Dichlorobenzene & $0.030^{*} \pm 0.52$ & $0.000 \pm 0.00$ & $0.000 \pm 0.00$ & 0.000 & 0.000 \\
\hline 1,4-Dichlorobenzene & $0.290^{*} \pm 0.38$ & $0.463^{*} \pm 0.11$ & $0.000 \pm 0.00$ & 2.000 & 0.000 \\
\hline 1,2-Dichlorobenzene & $0.000 \pm 0.29$ & $0.000 \pm 0.00$ & $0.000 \pm 0.00$ & 0.000 & 0.000 \\
\hline Total BTEX & $14.270 \pm 0.12$ & $45.429^{*} \pm 0.38$ & $20.146 \pm 0.68$ & - & - \\
\hline
\end{tabular}

Asterisked $(*)$ numbers imply significantly higher $(p<0.05)$. Numbers with same superscripts are no significantly different $(p>0.05)$. Italicized bioaccumulation factors imply significant figures $(=$ or $>1$ ). BAF I/W bioaccumulation factor of intestine relative to water, BAF P// bioaccumulation factor of parasite relative to intestine

within the period of study was Fish intestine $>$ Parasite $>$ Water.

The intestine of $S$. clarias highly bioaccumulated benzene (6) and $\mathrm{m}+\mathrm{p}$-Xylene (7). Furthermore, the intestine of the fish considerably bioaccumulated almost all the components of BTEX from the aqueous phase except 1,3-dichlorobenzene and 1,2-dichlorobenzene. While the parasite bioaccumulated ethylbenzene, $\mathrm{m}+\mathrm{p}$-xylene, and $\mathrm{o}$-xylene only, from the intestine of the host fish.

There was a significant regression $\left(\mathrm{R}^{2}=0.1947, p\right.$ value $=0.878$ ) of partition coefficients of BTEX in the parasite on the partition coefficients in the intestine of fish (Fig. 2). Concentration of BTEX in the intestine of fish was in the order of benzene $>\mathrm{m}+\mathrm{p}$-xylene $>$ ethylbenzene $>$ oxylene $>$ toluene $>$ chlorobenzene $>$ 1,4-dichlorobenzene $>$ 1,3-di-chlorobenzene.

The concentrations of alpha benzene hexachloride $(\alpha-\mathrm{BHC})$, beta benzene hexachloride $(\beta-\mathrm{BHC})$, gamma benzene hexachloride $(\gamma$-BHC), delta benzene hexachloride (d-BHC), and 4,4-dichloro diphenyl dichloroethylene (4,4-DDE) were below detection limits in all the media (Table 4). The concentrations of 4,4-dichloro diphenyl trichloroethane 4,4-(DDT), endosulfan 1, and aldrin detected in $W$. acuminata was significantly higher than the concentrations in the fish host $(p<0.05)$. There was no significant difference in the concentrations of other OCPs among the environmental matrices $(p>$ $0.05)$. The order of total OCPs in the tested environmental media was water $(5.89 \pm 0.38)$, parasite $(0.868 \pm 0.01)$, host fish $(0.437 \pm 0.02)$. The order of OCPs in the water medium was 4,4-DDT $>$ aldrin $>$ endosulfan $1>$ heptachlor $>$ others. Significant bioaccumulation factors of OCPs were observed only in the parasites in order of aldrin $(8.00)>4,4-D D T \quad(1.91)>$ heptachlor $\quad(1.04)>$ endosulfan $1(1.00)>$ others (0). No significant bioaccumulation was observed in host fish.

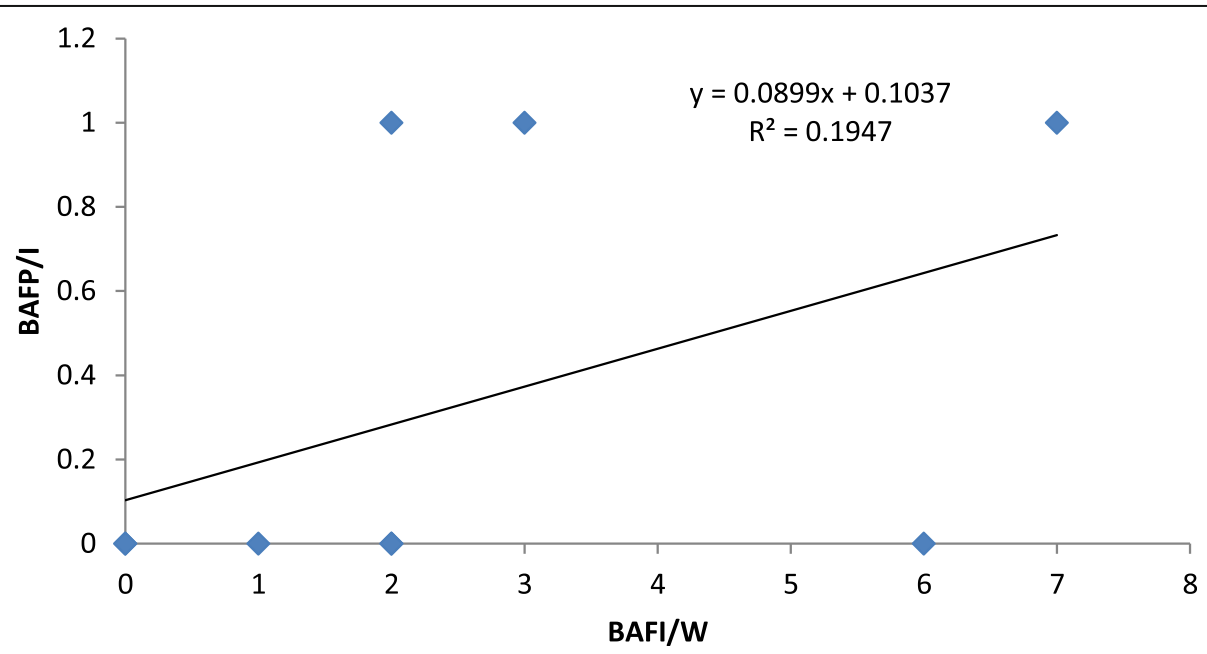

Fig. 2 Linear regression of bioaccumulation factor of BTEX in parasite relative to intestine against bioaccumulation in intestine relative to water 
Table 4 Bio-concentration factor of OCPs in water-fish (S. clarias)-parasite (W. acuminata) OCP congeners

\begin{tabular}{|c|c|c|c|c|c|c|}
\hline Classes (ppm) & Congeners & $\begin{array}{l}\text { Water (ppm) } \\
\text { Mean } \pm \text { SD }\end{array}$ & $\begin{array}{l}\text { Intestine (ppm) } \\
\text { Mean } \pm \text { SD }\end{array}$ & $\begin{array}{l}\text { Parasite (ppm) } \\
\text { Mean } \pm \text { SD }\end{array}$ & BAFi/w & BAFp/i \\
\hline \multirow[t]{4}{*}{ Lindane } & $a-B H C$ & $0.000 \pm 0.00$ & $0.000 \pm 0.00$ & $0.000 \pm 0.00$ & 0.000 & 0.000 \\
\hline & $\beta-B H C$ & $0.000 \pm 0.00$ & $0.000 \pm 0.00$ & $0.000 \pm 0.00$ & 0.000 & 0.000 \\
\hline & $\gamma-\mathrm{BHC}$ & $0.000 \pm 0.00$ & $0.000 \pm 0.00$ & $0.000 \pm 0.00$ & 0.000 & 0.000 \\
\hline & $\mathrm{d}-\mathrm{BHC}$ & $0.000 \pm 0.00$ & $0.000 \pm 0.00$ & $0.000 \pm 0.00$ & 0.000 & 0.000 \\
\hline \multirow[t]{2}{*}{ DDT } & 4,4-DDE & $0.000 \pm 0.00$ & $0.000 \pm 0.00$ & $0.000 \pm 0.00$ & 0.000 & 0.000 \\
\hline & 4,4-DDT & $5.761 \pm 0.38$ & $0.411 \pm 0.02$ & $0.793^{*} \pm 0.01$ & 0.071 & 1.929 \\
\hline \multirow[t]{6}{*}{ Cyclodiene } & Endosulfan 1 & $0.041^{*} \pm 0.00$ & $0.000 \pm 0.00$ & $0.041^{*} \pm 0.00$ & 0.000 & 1.000 \\
\hline & Aldrin & $0.059^{* *} \pm 0.00$ & $0.001 \pm 0.00$ & $0.008^{*} \pm 0.00$ & 0.017 & 8.000 \\
\hline & Dieldrin & $0.000 \pm 0.00$ & $0.000 \pm 0.00$ & $0.000 \pm 0.00$ & 0.000 & 0.000 \\
\hline & Endrin & $0.000 \pm 0.00$ & $0.000 \pm 0.00$ & $0.000 \pm 0.00$ & 0.000 & 0.000 \\
\hline & Heptachlor & $0.030 \pm 0.00$ & $0.025 \pm 0.00$ & $0.026 \pm 0.00$ & 0.833 & 1.040 \\
\hline & Heptachlor-Epoxide & $0.000 \pm 0.00$ & $0.000 \pm 0.00$ & $0.000 \pm 0.00$ & 0.000 & 0.000 \\
\hline Total OCP & & $5.89 \pm 0.38$ & $0.437 \pm 0.02$ & $0.868 \pm 0.01$ & - & - \\
\hline
\end{tabular}

Asterisked $\left(^{*}\right)$ numbers imply significantly higher $(p<0.05)$. Numbers with same superscripts are no significantly different $(p>0.05)$. Italicized bioaccumulation factors imply significant figures (= or $>1$ ). BAF I/W bioaccumulation factor of intestine relative to water, BAF $P / /$ bioaccumulation factor of parasite relative to intestine

There was no significant regression $\left(\mathrm{R}^{2}=0.0013, p\right.$ value $=0.214$ ) of partition coefficients of OCPs in the parasite on the partition coefficients of the compounds in the intestine of the host fish (Fig. 3).

Figure 4 shows BTEX was distinctively of higher concentration in the intestine of the S. clarias than OCPs across the comparisons (Fig. 4).

\section{Discussion}

The values recorded for the water parameters measured showed a slightly alkaline $\mathrm{pH}$ of 6.5 and an average electrical conductivity of $172.8 \mu \mathrm{S} / \mathrm{cm}$. The relatively high dissolved oxygen of $8.7 \mathrm{mg} / \mathrm{L}$ can be attributed to the shallowness of the water body, lack of thermal stratification and an effective regular mixing due to tidal movement which are features of a well aerated water body, the total suspended solids value of $9 \mathrm{mg} / \mathrm{L}$ inferences a high water clarity which corroborates the observed relatively low turbidity of 8.57 NTU, total dissolved solids of $110.1 \mathrm{mg} / \mathrm{L}$ which is an indication of average nutrient content. A salinity of $4.5 \mathrm{ppt}$ which is characteristic of estuarine.

High concentrations of most BTEX components such as benzene, toluene, chlorobenzene, ethylbenzene, $\mathrm{m}+$ p-xylene, and o-xylene bioaccumulated into the intestinal tissues of $S$. clarias from the water medium. This implicated in this observation. Despite the bioavailability of BTEX components in the intestine of $S$. clarias,

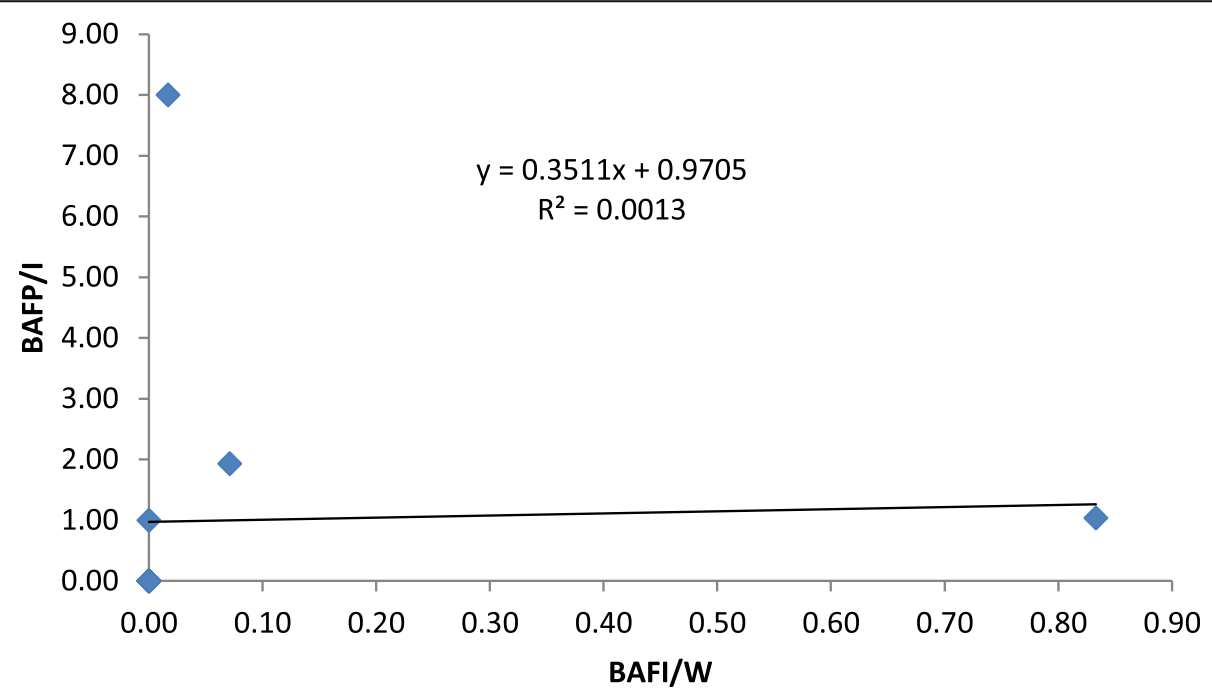

Fig. 3 Linear regression of bioaccumulation factor of OCP in parasite relative to intestine against bioaccumulation in intestine relative to water 


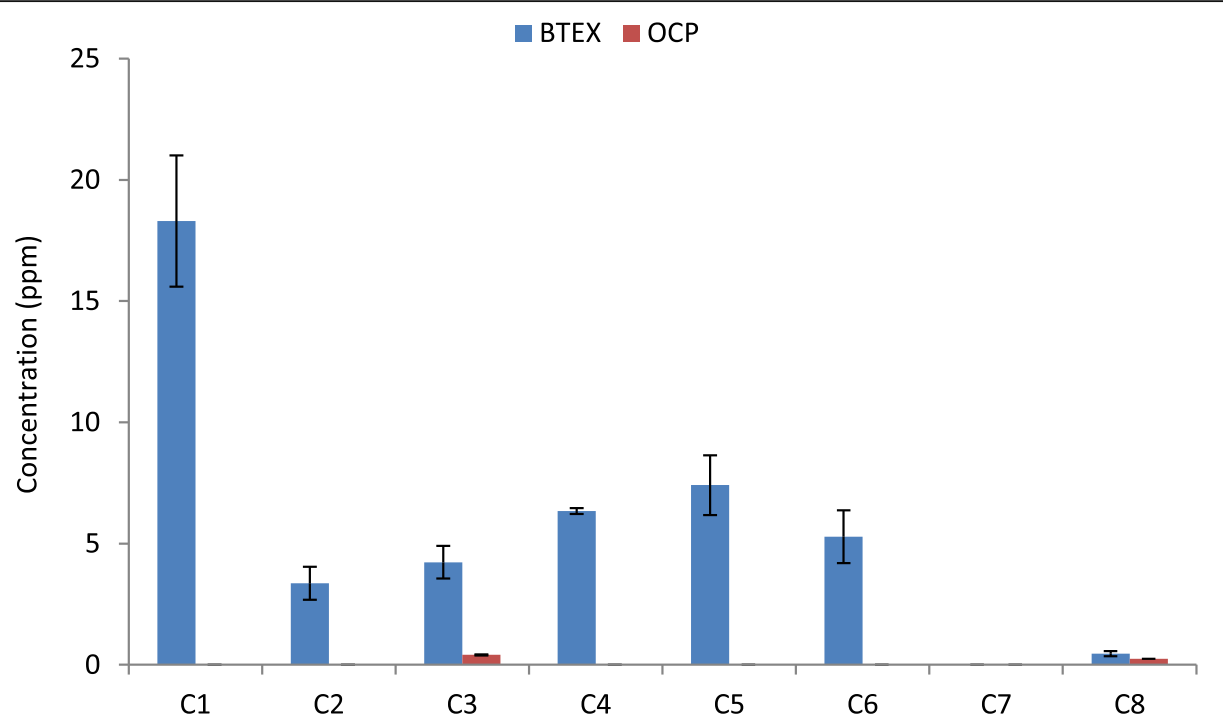

Fig. 4 Comparative concentrations of BTEX components and OCP congeners in the tissue of S. clarias. BTEX: benzene (C1), toluene (C2), chlorobenzene (C3), ethylbenzene (C4), $m+$ p-xylene (C5), o-xylene (C6), 1,3-dichlorobenzene (C7), and 1,4-dichlorobenzene (C8). OCP: $d$-BHC (C1), 4,4-DDE (C2), 4,4-DDT (C3), endosulfan 1 (C4), aldrin (C5), dieldrin (C6), endrin (C7), and heptachlor (C8)

results show that the tissue of $W$. acuminata had low affinity for the constituent chemicals. The only exceptions were ethylbenzene, $\mathrm{m}+\mathrm{p}$-xylene, and $\mathrm{o}$-xylene in which average bioaccumulations were observed. The significant regression of BAF in $W$. acuminate relative to that of $S$. clarias is a function of coefficient of partition of ethylbenzene, $\mathrm{m}+\mathrm{p}$-xylene, and o-xylene.

High partition coefficients are implicated in the significant bioaccumulations of benzene, toluene, chlorobenzene, ethybenzene, $\mathrm{m}+\mathrm{p}$-xylene, 1,4-dichlorobenzene observed in the fish. In the parasite on the other hand, all BTEX compounds, except ethylebenzene and $\mathrm{m}+\mathrm{p}$-xylene had significant partition coefficients which was evidenced by the significant bioaccumulation factors of the compounds. Results showed high vulnerability of the fish to BTEX compounds in the aquatic habitat.

Furthermore, the parasites showed inability to absorb appreciable amounts of BTEX from its host, as evidenced in the insignificant regression of partition coefficient of BTEX in the parasite on the partition coefficient in the host. This implies that BTEX toxicity burden of $S$. clarias could not be ameliorated by $W$. acuminate. The trend of BTEX components in tested environmental media was fish intestine $>$ parasite $>$ water. The analyses of $100 \%$ WSF of petroleum of the present investigation showed low concentration of BTEX in parasite, high in fish intestine, and average in water. A similar composition has been reported by other authors (Anderson, Neef, Cox, Tatem, \& Hightower, 1974; Neff, Ostazeski, Gardiner, \& Stejskal, 2000).

Bioaccumulation factor of BTEX in S. clarias was in the order of benzene $>$ chlorobenzene $>$ toluene $=$ ethylbenzene $=(\mathrm{m}+\mathrm{p}$-xylene $)=(\mathrm{o}-$ xylene $)=1,3$-dichlorobenzene $>1$,4-dichlorobenzene $>1,2$-dichlorobenzene. This trend conforms to observations from previous studies (Anderson, Neef, Cox, Tatem, \& Hightower, 1974; Neff, Ostazeski, Gardiner, \& Stejskal, 2000; Saeed \& Al-Mutairi, 1999; Simonato, Guedes, \& Martinez, 2008).

Generally, low concentrations of OCPs in the water medium can be attributed to the alkalinity of the water in the lagoon, a factor which reduces the bioavailability of compounds (Ramachandran et al., 2006; Shukla, Gopalani, Ramteke, \& Wate, 2007). Baumard et al. (1999) earlier suggested several other factors, such as organic matter composition, $\mathrm{pH}$, and temperature which affect bioavailability and distribution of hydrocarbons. OCPs such as $\alpha$-BHC, $\beta$-BHC, $\gamma$-BHC, $d-B H C$, and 4,4-DDE were absent in all environmental media. $W$. acuminata exhibited significant bioaccumulation of 4,4-DDT, endosulfan 1, aldrin, and heptachlor, irrespective of their concentrations in the water and intestine of S. clarias. This indicates high affinity for the OCPs in the parasites. Results show that bioaccumulation of the detected OCPs in the parasites does not depend on the bioaccumulation in the host. Furthermore, as illustrated in Fig. 4, although the concentrations of BTEX were quite higher than the concentrations of OCPs in the host fish, the parasite was able to magnify the concentration of the latter due to its high bioaccumulation capacity for the xenobiotic despite the low percentage. Similar observation was earlier made by Jirsa, Leodolter-Dvorak, Krachler, and Frank (2008) in which higher concentrations of $\mathrm{Cd}, \mathrm{Pb}$, and $\mathrm{Zn}$ Caryophyllaeus laticeps detected than the host. Akinsanya, Goh, 
Lim, and Tinga (2015) earlier pointed out that parasites may possess remarkable accumulation potentials for hydrophilic substances.

Comparisons on toxicological effects of crude oil WSF are difficult, because hydrocarbon concentrations present in the petroleum are extremely variable according to its origin (Neff, Ostazeski, Gardiner, \& Stejskal, 2000). Other factors can be described like the different methodologies applied for WSF preparation (Saeed \& Al-Mutairi, 1999; Singer et al., 2000), and distinct tolerance to crude oils presented by different species (Ramachandran et al., 2006). However, the toxicity of crude oil WSF seems to be higher in freshwater than in seawater species, and this fact might be related to hydrocarbon solubility and higher bioaccumulation in fish when salinity is reduced (Ramachandran et al., 2006; Shukla, Gopalani, Ramteke, \& Wate, 2007). Different investigations have shown that the WSF of refined petroleum products generally are more toxic than their respective crude oils (Anderson, Neef, Cox, Tatem, \& Hightower, 1974; Rayburn, 1996). Anderson, Neef, Cox, Tatem, and Hightower (1974) reported that WSFs of number 2 fuel oil and bunker $C$ are more toxic than crude oil WSF. Comparable results were found between toxicities of WSF of diesel and gasoline for the mysid shrimp Metamysidopsis insularis (Mohammed, 2005). Barron et al. (1999), González-Doncel, González, Fernández-Torija, Navas, and Tarazona (2008), and Neff, Ostazeski, Gardiner, and Stejskal (2000) evaluated the toxicity of WSF of different sources of petroleum hydrocarbons and concluded that the PAHs are not the major determinant of the toxicity of WSF for marine organisms.

BTEX and OCPs contamination of Lagos waters is expected to increase following increased anthropogenic activities which are potential sources of xenobiotics such as BTEX and OCPs into waterways. Such anthropogenic activities include construction of more jetties and crude oil discharge ports.

\section{Conclusion}

Synodontis clarias of Lekki lagoon are much more vulnerable to the BTEX than the OCPs in the aquatic habitat. This implies that Lekki lagoon is impacted by oilrelated anthropogenic activities. The study has shown the importance of biomonitoring of benzene, toluene, chlorobenzene, ethylbenzene, $\mathrm{m}+\mathrm{p}$-xylene, and 1,4-dichlorobenzene in Lekki lagoon.

\footnotetext{
Abbreviations

ү-BHC: Gamma benzene hexachloride; 4,4-DDE: 4,4-Dichloro diphenyl dichloroethylene; 4,4-DDT: 4,4-Dichloro diphenyl trichloroethane; BAF I/ W: Bioaccumulation factor of intestine relative to water; BAF P/I: Bioaccumulation factor of parasite relative to intestine; BTEX: Benzene, toluene, ethylbenzene, and xylene; d-BHC: Delta benzene hexachloride; $\mathrm{m}$ + p-xylene: Meta- and para-xylene; MI: Mean intensity of parasite; NE: Number examined; NI: Number infected; OCP: Organochloride phosphate; O-xylene: Ortho-xylene; SL: Standard length; a$\mathrm{BHC}$ : Alpha benzene hexachloride; $\beta$-BHC: Beta benzene hexachloride
}

\section{Acknowledgements}

We appreciate the laboratory of the Department of Veterinary Pathology, University of Ibadan, Nigeria, for maintaining quality assurance, and quality control in the research.

\section{Funding}

The research was not funded.

\section{Availability of data and materials \\ Metadata will be provide upon request.}

\section{Authors' contributions}

$A B$ designed the study and verified data. IPO wrote the manuscript and made corrections. KMP processed and analyzed data. SJK collected, preserved, and analyzed samples. DEO searched for literature and interpreted data. All authors read and approved the final manuscript.

\section{Ethics approval and consent to participate}

Not applicable.

\section{Consent for publication}

The research did not involve human subjects.

\section{Competing interests}

The authors declare that they have no competing interests.

\section{Publisher's Note}

Springer Nature remains neutral with regard to jurisdictional claims in published maps and institutional affiliations.

\section{Author details}

${ }^{1}$ Department of Biological Science, Covenant University, Ota, Ogun State, Nigeria. ${ }^{2}$ Applied Biology and Biotechnology Unit, Department of Biological Science, Covenant University, Ota, Nigeria. ${ }^{3}$ Department of Marine Sciences, University of Lagos, Lagos, Nigeria. ${ }^{4}$ Department of Cell Biology and Genetics, University of Lagos, Akoka, Yaba, Lagos, Nigeria.

Received: 11 January 2019 Accepted: 26 March 2019

Published online: 10 June 2019

\section{References}

Adeyemi, D., Ukpo, G., Anyakora, C., \& Unyimadu, J. P. (2008). Organochlorine pesticide residues in fish samples from Lagos lagoon, Nigeria. American Journal of Environmental Sciences, 4(6), 649-653.

Afful, S., Anim, A., \& Serfor-Armah, Y. (2010). Spectrum of organochlorine pesticide residues in fish samples from the Densu Basin. Research Journal of Environmental and Earth Sciences, 2(3), 133-138.

Akinsanya, M. A., Goh, J. K., Lim, S. P., \& Tinga, A. S. Y. (2015). Metagenomics study of endophytic bacteria in Aloevera using next-generation technology. Genomics Data, 6, 159-163. https://doi.org/10.1016/j.gdata.2015.09.004.

Akinsanya, B., Otubanjo, O. A., \& Hassan, A. A. (2007). Helminth parasites of Malapterurus electricus Malapteruridae from Lekki lagoon, Lagos, Nigeria. Journal of American Science, 3(3), 1-5.

Akinsanya, B., Ukwa, U. D., \& Hassan, A. A. (2014). Effect of host condition on intestinal parasite load and prevalence in Malapterurus electricus, Gmelin 1789, (Siluriformes: Malapteridae) in Lekki lagoon, Lagos, Nigeria. Nigeria Journal of Parasitology, 35, 59-64.

Akinsanya, B., Isibor, P. O., Kuton, M. P., Saliu, J. K., Dada, E. O. (2019). Aspidogastrea africanus Infections, comparative assessment of BTEX and heavy metals Bioaccumulation, and histopathological alterations as biomarker response in Chrysichthyes nigrodigitatus (Lacépède, 1803) of Lekki Lagoon, Nigeria. Scientific African 3 (2019) e0 0060.

Anderson, J. W., Neef, J. M., Cox, B. A., Tatem, H. E., \& Hightower, G. M. (1974). Characteristics of dispersions and water-soluble extracts of crude and refined oils and their toxicity to estuarine crustaceans and fish. Marine Biology, 27, 75-88.

ASTM (1997) Method D2887-93, Test method for boiling range distribution of petroleum fractions by gas chromatography. In: Annual Book of ASTM Standards. Philadelphia: American Society for Testing and Materials 05. p. 27. 
Barron, M.G., Podrabsky, T., Ogle, S., Ricker, R.W. (1999). Are aromatic hydrocarbons the primary determinant of petroleum toxicity to aquatic organisms? Aquat. Toxicol. 46, 253-268.

Baumard, P. Buzinski, H., Garrigues, P., Narbonne, J. F. Burgeot, T., Michel, X., and Bellocq, J. (1999). Polycyclic aromatic hydrocarbons (PAH) burden of mussels (Mytilus sp.) in different marine environments in relation to sediment PAH contamination and bioavailability. Marine Environmental Research 47, 415-439.

Belta, G. D., Likata, P., Bruzzese, A., Naccarri, C., Trombetta, D., Turco, V. L., Naccari, F. (2006). Level and congener pattern of PCBs and OCPs residues in blue-fin tuna (Thunnus thynnus) from the straits of Messina (Sicily, Italy). Environment International, 32, 705-710.

Blaso, C., Font, G., \& Pico, Y. (2005). Analysis of pesticides in fruits by pressurized liquid extraction and liquid chromatography-ion trap-triple stage mass spectrometry. Journal of Chromatography A, 1098, 37-43.

Bouman, H. (2004). South Africa and the Stockholm on persistent organic pollutants. African Journal of Science, 100, 323-328.

Breeder, C. M., \& Rosen, D. E. (1966). Modes of reproduction in fishes. Neptune City: T.F.H. Publications.

Colborn, T., \& Smolen, M. J. (1996). Epidemiological analysis of persistent organochlorine contaminants in cetaceans. Reviews of Environmental Contamination and Toxicology, 146, 91-172.

Edokpayi, C. A., Uwadiae, R. E., Asoro, A. O., \& Badru, A. E. (2008). Phytomacroinvertebrates arthropods associated with the roots of Eichorrnia crassipes (water hyacinth) in a tropical west African lagoon. Ecology, Environment and Conservation, 14(2-3), 241-247.

Ezewanji, N. E., Aguigwo, J. N. I., Philip, C. O., \& Ezewanji, H. M. G. (2005). Helminthendo-parasites of mochokids in a tropical rainforest river system. Annual Research International, 2(2), 346-352.

Federal Environmental Protection Agency (FEPA) (2003). Guidelines and standards for environmental pollution control in Nigeria, (p. 420).

Garabrant, D. H., Held, J., Langholz, B., Peter, J. M., \& Mark, T. M. (1992). DDT and related compounds and risk of pancreatic cancer. Journal of the National Cancer Institute, 84, 764-771.

González-Doncel, M., González, L., Fernández-Torija, C., Navas, J. M., \& Tarazona, J. V. (2008). Toxic effects of an oil spill on fish early life stages may not be exclusively associated to PAHs: Studies with prestige oil and medaka (Oryzias latipes). Aquatic Toxicology, 87, 280-288.

Inyang, A. I., Sunday, K. E., \& Dan, M. U. (2016). Effect of hydroclimatic condition on phytoplankton community at Epe lagoon tributary, Southwest Nigeria. Journal of Oceanography and marine Sceince, 7(2), 12-23.

Ize-lyamu, O. K., Asia, I. O., \& Egwakhide, P. A. (2007). Concentrations of residues from organochlorine pesticide in water and fish from some rivers in Edo state Nigeria. International Journal of Physical Sciences, 2(9), 237-241.

Jirsa, F., Leodolter-Dvorak, M., Krachler, R., \& Frank, C. (2008). Heavy metals in the Nasus Chondrostoma nasus (L. 1758), and its intestinal parasite Caryophyllaeus laticeps (Pallas 1781) from Austrian rivers: Bioindicative aspects. Archives of Environmental Contaminants and Toxicology. https://doi.org/10.1007/s00244-008-9154-1.

Kolpin, D. W., Thurman, E. W., \& Lingart, S. M. (1998). The environmental occurrence of herbicides: the importance of degradates in ground water. Bulletin of Environmental Contamination and Toxicology, 35, 385-390.

Kusemiju, K. (1981). The hydrobiology and fishes of the Lekki lagoon. Nigeria Journal of Natural Sciences, 3, 135-146.

Lawal, I. O., Uzokwe, N. E., Igboanuyo, A. B., Adio, A. F., Awosan, E. A. Nwogwugwu, J. O., Adesoya, A. A. (2010). Ethnomedicinal information on collation and identification of some medical plants in research institutes of Nigeria. African Journal of Pharmacy and Pharmacology, 4(1), 001-007.

Mohammed, A. (2005). Toxicity of water-soluble fractions of four fuels for Metamysidopsis insularis, an indigenous tropical mysid species. Environmental Monitoring and Assessment, 104, 37-44.

Neff, J. M., Ostazeski, S., Gardiner, W., \& Stejskal, I. (2000). Effects of weathering on the toxicity of three offshore Australian crude oils and a diesel fuel to marine animals. Environmental Toxicology and Chemistry, 19(7), 1809-1821.

Osibanjo, O., \& Bamgbose, O. (1990). Chlorinated hydrocarbons in marine fish and shellfishes of Nigeria. Marine Pollution Bulletin, 21, 581-586.

Osibanjo, O., Bashin, N., Onyoyo, H., Bouwman, H., Yive, R., \& Okond'Ohoka, J. (2002). UNEP/GEF regionally based assessment of persistent toxic substances, sub-Saharan Africa regional report.

Ramachandran, S. D., Sweezey, M. J., Hodson, P. V., Boudreau, M., Courtenay, S. C., Lee, K., et al. (2006). Influence of salinity and fish species on PAH uptake from dispersed crude oil. Marine Pollution Bulletin, 52, 1182-1189.
Raposo, M. S., Marks, D. F., \& Cutler (2007). Lysosome-related organelles: driving postgolgi compartments into specialization. Current Opinion in Cell Biology, 19, 394-401.

Rayburn, S.R. (1996). Characterization of grass shrimp (Palaemonetes pugio) embryo toxicity test using the water-soluble fraction of number 2 fuel oil. Mar. Pollut. Bull., 32, 860-866.

Riede, K. (2004). Global register of migratory species from global to regional scales. Final report of $R \&$ D-Projekt 80805081, (p. 329). Bonn: Federal Agency for Nature conservation.

Saeed, T., \& Al-Mutairi, M. (1999). Chemical composition of the water-soluble fraction of leaded gasolines in sea water. Environment International, 25, 117-129.

Saliu, A., Adise, S., Xian, S., Kudelska, K., \& Rodriguez-Contreras, A. (2014). Natural and lesion-induced decrease in cell proliferation in medial nucleus of the trapezoid body during hearing development. Journal of Comparative Neurology, 522(5), 971-985.

Shukla, P., Gopalani, M., Ramteke, D. S., \& Wate, S. R. (2007). Influence of salinity on PAH uptake from water-soluble fraction of crude oil in Tilapia mossambica. Bulletin of Environmental Contamination and Toxicology, 79, 601-605.

Simonato, J. D., Guedes, C. L. B., \& Martinez, C. B. R. (2008). Biochemical, physiological, and histological changes in the neotropical fish Prochilodus lineatus exposed to diesel oil. Ecotoxicology and Environmental Safety, 69(1), 112-120.

Singer, M. M., Aurand, D., Bragin, G. E., Clark, J. R., Coelho, G. M., Sowby, M. L., et al. (2000). Standardization of the preparation and quantitation of wateraccommodated fractions of petroleum for toxicity testing. Marine Pollution Bulletin, 40, 1007-1016.

Sogbanmu, T. O., Nagy, E., Philips, D. H., Arlt, V. M., otitoloju, A. A., \& Bury, R. N. (2016). Lagos lagoon sediment organic extract and polycyclic aromatic hydrocarbons induce embryotoxic, teratogenic and genotoxic effects in Danio rerio (zebra fish) embryos. Environmental Science and Pollution Research, 23, 14489-14501.

Unyimadu, J. P., \& Udochu, A. (2002). Comparative studies of organochlorine and PCBs in fish from the Lagos lagoon. River Elber Saar. Journal of Agricultural Biotechnology: Environmental, 4(1-2), 14-17.

William, J., Tagoe, L., Drechsel, P., Kelderman, P., Gijzen, H., \& Nyarko, E. (2008). Accumulation of persistence organochlorine contaminants in milk and serum of farmers from Ghana. Environmental Research, 106, 17-26.

Yao, T., Hea, C., Zhangb,P., Gaob, H., Zhou, C. (2013). Distribution and sources of polychlorinated biphenyls (PCBs) and organochlorine pesticides (OCPs) in surface waters of Jinzhou Bay in China Procedia Environmental Sciences, 18, $317-322$

\section{Submit your manuscript to a SpringerOpen ${ }^{\circ}$ journal and benefit from:}

- Convenient online submission

- Rigorous peer review

- Open access: articles freely available online

High visibility within the field

- Retaining the copyright to your article

Submit your next manuscript at $\boldsymbol{\sim}$ springeropen.com 